\title{
Risk MANAgEMENT: An ADAPTATION FOR A SME
}

\section{FENOLLERA, M. \& LORENZO, J.}

Abstract: The Project we are about to analyze, "Design and manufacture of eight fender davits", was a significant strategic project in 2010. It began as such at the request of a customer who manages his projects by following the guidelines of Project Management Body of Knowledge (PMBok); this project's success was a milestone, since it meant the introduction of the SME into a highly competitive new market.

The authors present the "adaptation" of this SME to the Project Management Institute (PMI) standards for project management, and specifically for risk management. The risk management approach undertaken is described, with the characteristic features of a SME: stages of the process, people implied with their roles and responsibilities, implemented activities, used metrics, conducted monitoring and control,...And what the results obtained have been.

Key words: SME; PMI; risk management; adaptation; naval sector
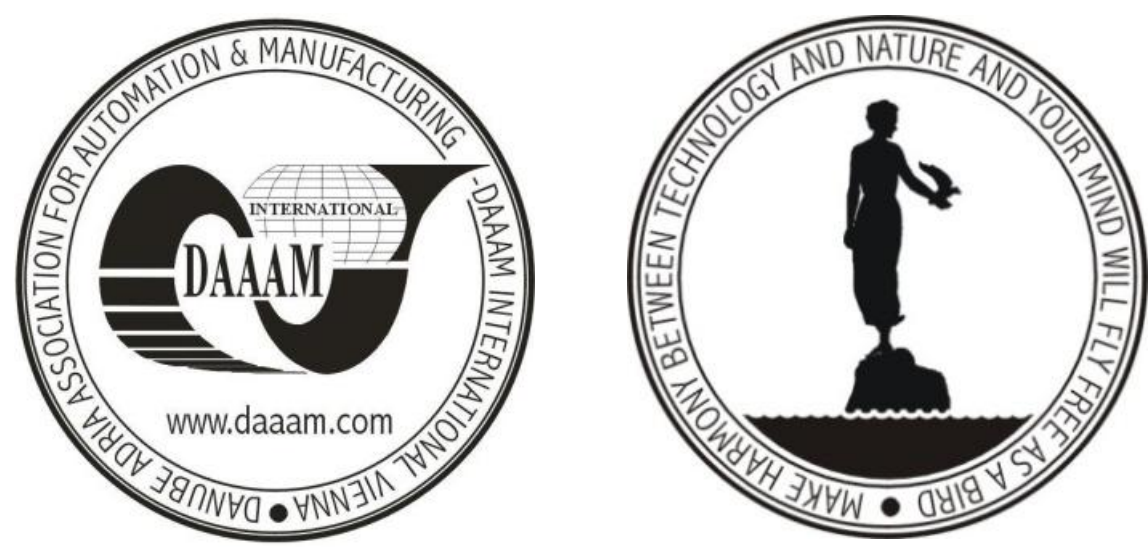

Authors' data: Univ.Prof. Ing. Fenollera, M[aria]; Ing. Lorenzo, J[aime]; University of Vigo, E.T.S.Industrial Engineers. Campus Lagoas Marcosende s/n Vigo.Spain,mfenollera@uvigo.es

This Publication has to be referred as: Fenollera, M[aria] \& Lorenzo, J[aime] (2011). Risk Management: An Adaptation for a SME, Chapter 39 in DAAAM International Scientific Book 2011, pp. 474-494, B. Katalinic (Ed.), Published by DAAAM International, ISBN 978-3-901509-84-1, ISSN 1726-9687,Vienna, Austria DOI: $10.2507 /$ daaam.scibook.2011.39 


\section{Introduction}

As the PMI defines it, a risk is an uncertain event or condition which, should it occur, will have a positive or negative effect on the project's objectives. A project's risk management practice does not substitute other management processes, but it adds value, since the most realistic expectations of the project's results are obtained (PMI, 2009). A project can be approached in countless ways, and all have different risk implications. The aim was to find proper indicators for particular processes and to find methodology that would help identify those indicators (Nagyova \&Pacaiova, 2009).

There are an increasing number of project-oriented companies. In them, each of the customer's order automatically becomes a "project" for the company. Much has been written about risk management in big companies, but there is little bibliography on the use of the PMI methodology in SME. Examples are the studies of Delisle \& St-Pierre (2003), Blanc-Alquiler \& Lagasse-Tignol (2006) and Rosu et al. (2010) but their application is restricted and are usually developed for projectoriented organizations.

Our SME case study is not one of these companies: it tends to quickly focus on the project's objectives and to neglect planning and control; it usually implements the simplest possible management, centred on costs, deadlines and quality, forgetting risk management. However, as it aims to take the technological leap and to increase its competitiveness, it has made a huge effort over the past two years to combine its regular operations with one or several strategic projects, using PMI methodology in its risk management. It is aware that at the early stages of a project, the information about the risk can be minimal, but it is convinced that risk management according to PMI will imply that the risk is analyzed to the full, and thus such management becomes vital for its success.

The main problem with which a SME is confronted to implement this kind of methodologies is that the existing project management standards aimed at large projects. In fact, the customer is an important Fortune 500 American company involved in the exploitation, processing and distribution of oil products and natural gas, oriented toward very complex, large, long-duration projects. Based on Turner et al. (2009), has "guided" the SME throughout an appropriate risk management implementation. At the same time, the researchers from the School of Industrial Engineering, University of Vigo, have provided professional advice to the SME, actively participating all the time trying to bring together the points of view of both parts (customer and SME).

The main limitations of this research have been:

- Customer's requirements, trying to impose his criteria in managing the order.

- The short timeframe (one year) to deliver the order and all its specifications, to implement and adapt the PMI methodology.

- Scarce material, human and financial resources.

- Those relating to the adjustment of a methodology design for big projects to the case of this SME. 


\section{Background}

Naval construction industry is a key sector in Galicia, not only because of the number of direct and indirect jobs it creates, but also because of its significant impact on the socioeconomic environment as a whole, as well as a real source of professionals from the most diverse fields.

As in the rest of Europe, Galician naval sector has carried out an important adjustment effort for decades that forces both market driving and auxiliary industries to get adapted as a sector to the requirements set by a highly internationalized and competitive market. This situation forces competition in terms of added value in technologies, new production and management organization methods, new design processes, new distribution and communication channels...

As a strategy, the sector must reach the adequate efficiency and quality levels. This implies working in design optimization and product output, trying to reach a significant reduction in costs and building and manufacturing times.

It is at this point where the use of PMI methodology can mean an important competitive advantage, since highly complex projects are conducted in this sector, both regarding the work scope and critical deadline fulfillment and high budgets dealt with.

Fully aware of this, the company here concerned, has taken a technological leap in terms of increasing its competitiveness by using PMI methodology when managing its strategic projects. But, why this methodology? The advantages of introducing a corporative culture into project management, that justify the company's decision to implement it are as follow:

- Enables fast response to changing demands. Provides the ability to adapt to the change and to handle such change.

- Maximizes organization skills. Identifies the possible process improvements, and saves time and costs.

- Identifies all functional responsibilities regarding the fulfillment of the company's mission, making sure that all organization members are aware of their responsibility.

- Coordinates the different internal and external resources. In many occasions, the same supplier is in contact with different areas of the company and potential synergies not being used.

- Provides an overview and improves communication within the company. It makes possible to transfer knowledge among departments that would otherwise act independently.

- Establishes global objectives beyond the particular visions of each group, department or area. Handles the organization's total budget and costs. It makes it possible to establish priorities from the different pending actions.

- Enables learning from past lessons. A "know how" is created within the company through a correct project management; such experience can then be used for planning and executing future projects.

- Provides a correct perception about the real team capacity, since it maximizes the synergies among the different members.

- Allows for risk and problem identification at an early stage, thus permitting corrective actions to be designed on time. 
- It offers a customer-focused vision, since the Project Manager is generally the customer's speaker and defends his interests within the organization.

- Provides information to the Management and reduces the necessity of all team members to make reports constantly, as the information is taken up by the Project Manager.

- Ensures quality, since it provides the customer with a result in keeping with requirements and that complies with the use.

We have to bear in mind that a change, and especially the change associated to the establishment of a new methodology, affects not only the organization, but also each of the persons involved in the organization (Bovee and Ruwaard, 2004) and must be promoted from the management team to all levels in order to give the change the adequate importance.

Since organizations are made up of individuals, they will be the first making changes in their working method to boost a widespread change in the way a company carries out its activities. Human beings are reluctant to changes by nature, so promoting the cultural change within the company where the new methodology wants to be applied is vital to make the company easily assume the change introduced in the way of activities are carried out (Taylor, 2007).

After this short analysis of the sector's situation and the need for choosing this tool, the authors will present the "adaptation" of this SME to the PMI standards for project management, and specifically for risk management. And we refer to adaptation, since it is a mistake to assume that tools and techniques designed for large-scale projects can be used for managing small-scale projects without modifications (Rowe, 2007).

What was found out was:

- Order's delivery, fulfilling its specifications.

- The PMI methodology adapted to the company, creating its own management methodology according to the company's special characteristics.

- The implementation of a simple, smooth risk management, applicable in future projects.

\section{Case study}

This paper puts forward the experiences gathered from the adaptation of the PMI methodology to a SME from Galician naval auxiliary industry. It specifically deals with the different risk management implementation stages of a strategic project. The researchers' object of study is a SME that generates a turnover of 6 million euro and has 50 employees; over the past 45 years, it has provided design, manufacture, machinery and equipment for the naval sector; it is quality-oriented, makes reliable, efficient and solid equipments, among others: cranes, davits, winches, hooks, handling equipment.... It is worthy of mention staff key in the different departments having received training in this methodology through diverse courses provided by the Cluster of the Galician Naval Sector (ACLUNAGA), and management team having tried to promote its implementation. 
The characteristics of the order used as pilot of this methodology implementation are shown in Table 1 that presents the initial considerations about the project, which reflect its importance.

\begin{tabular}{|l|l|}
\hline \multicolumn{2}{|c|}{ PROJECT: FENDER DAVITS DESIGN AND MANUFACTURE } \\
\hline Order: & 4 pairs of davits for gas extraction platform \\
\hline Customer: & Strong Norwegian multinational company \\
\hline Delivery time: & 1 year from order's acceptance \\
\hline Price: & $1.300 .000 €(22 \%$ of turnover $)$ \\
\hline Estimated cost: & $800,000 €(38 \%$ profit $)$ \\
\hline Delay records: & 30 -day average delay \\
\hline Cost records: & $15 \%$ increase from initial budget \\
\hline
\end{tabular}

Tab. 1. Initial considerations about the project

The fender davits are used in the gas extraction platforms to hoist or to lower the fenders that prevent ships from being beaten against the platform. Figure 1 shows the project's technical characteristics: fender davits location in the platform (a), fender davits on the test bench (b) and different detailed drawings (c).

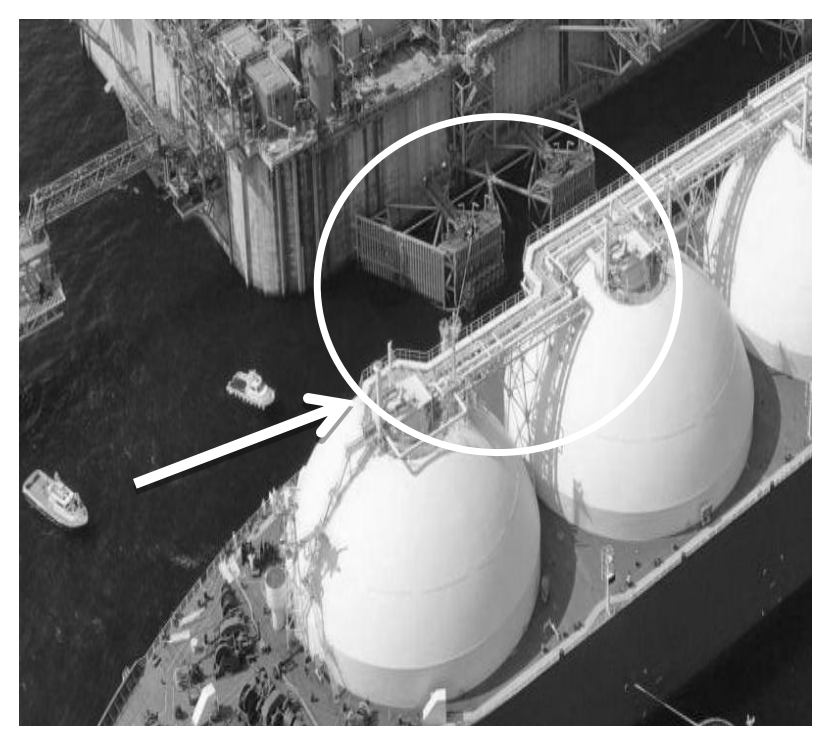

(a)

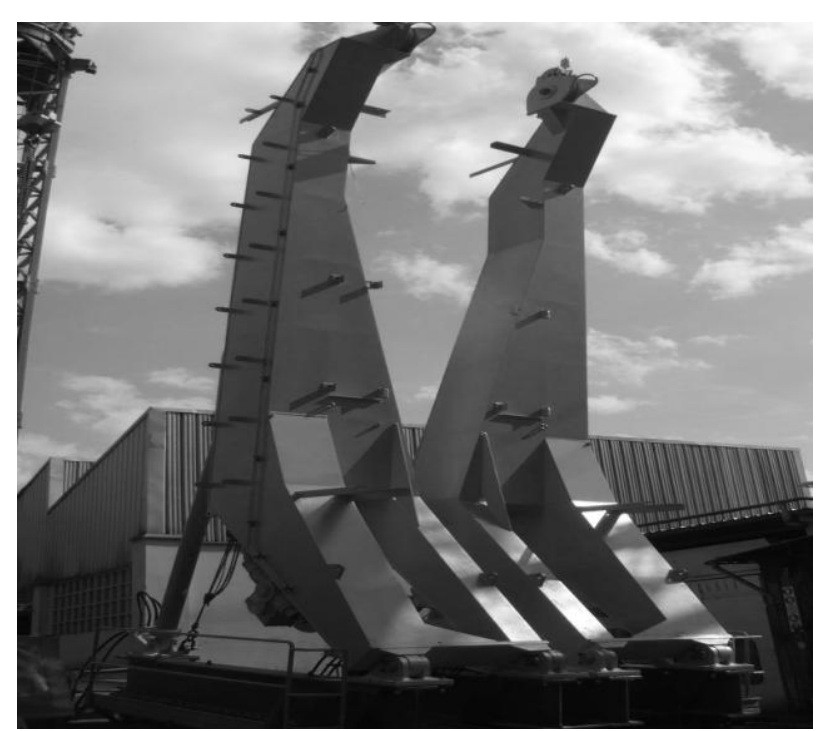

(b)

Fig. 1. (a) \& (b) Technical characteristics of fender davits

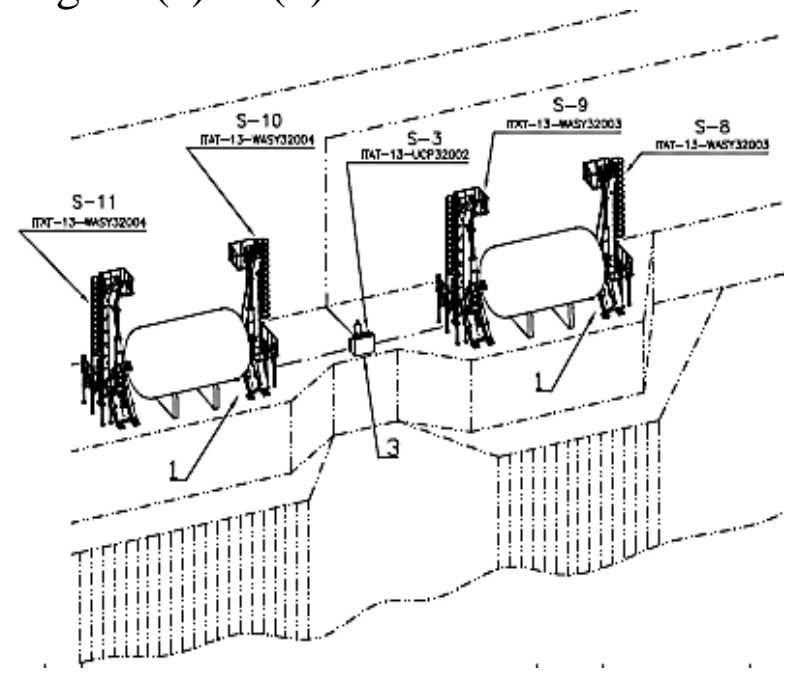

(c)

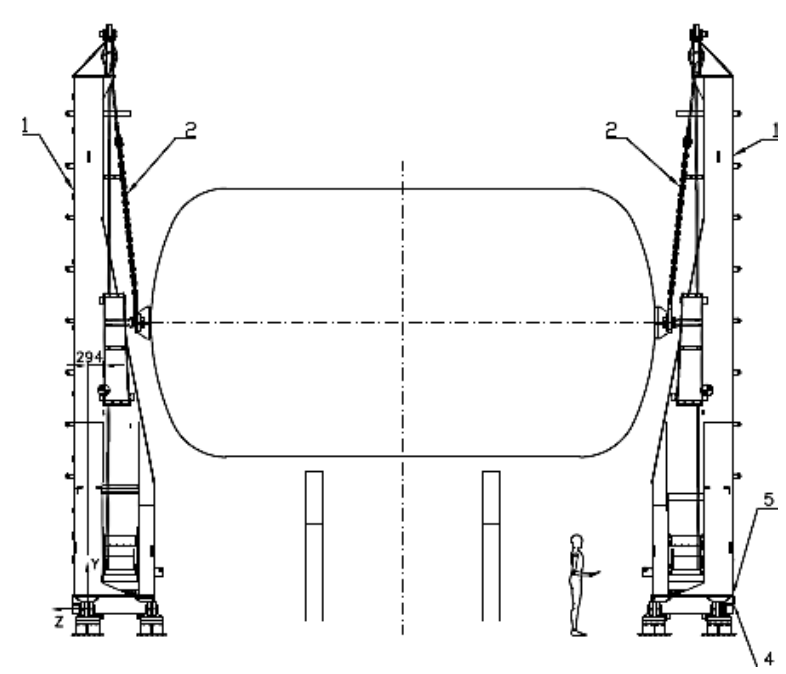


Fenollera, M. \& Lorenzo, J.: Risk Management: an Adaptation for a SME

Fig. 1. (c) Technical characteristics of fender davits

Taking PMI as a reference again, the aim of risk management is to describe the procedure for the identification, analysis, prioritization and monitoring of the risks associated to the project. In order to achieve this objective, researchers followed the methodology described in Figure 2 of its Risk Management Plan (RMP).

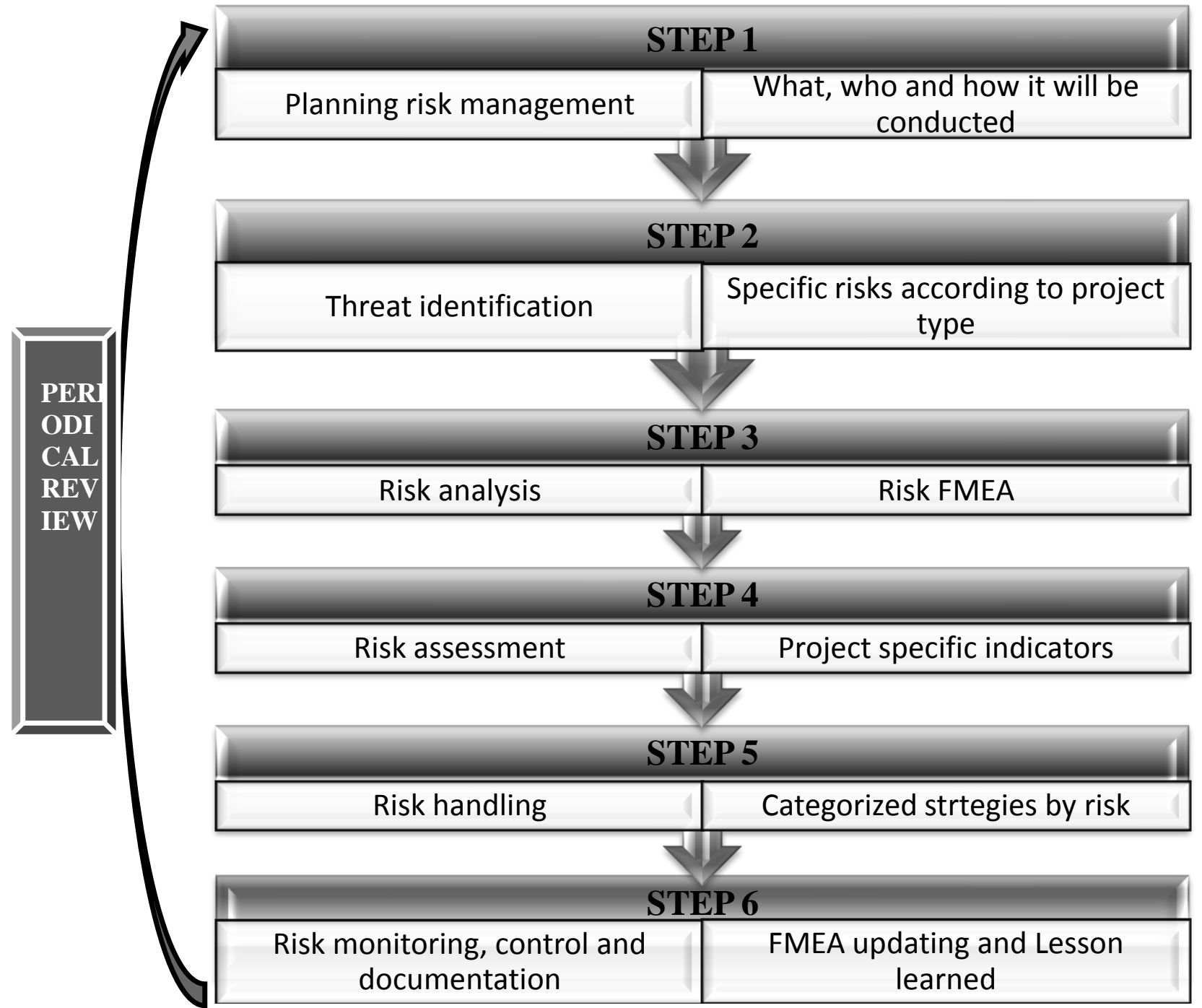

Fig. 2. Risk Management Plan.

The RMP comprised the following steps:

\section{STEP 1: PLANNING}

Risk management planning process covered:

- Organization

- Roles and responsibilities

- Action plan

- Monitoring

- Metrics

- Activities

- Risk and event records 
- Organization: the customer hired an external auditor coordinated the different agents implied and integrated the management of the risks identified in the several subprojects.

Risk management is one of the most important parts of the project risk management coordinator role, since it is him who must guarantee that the risks are identified, recorded, managed and regularly reviewed. Conducting an optimal risk management, entails eliminating, as far as possible, the threats associated to each of the risks, before they materialize.

- Roles and responsibilities: RMP chart defines three figures with their respective responsibilities, described in Figure 3 organization chart and in Table 2 roles and responsabilities:

- Risk management coordinator: the external auditor hired by the customer

- Subproject Manager: a person responsible for each of the subprojects into which the original project was divided has been designated.

- Member of team project: each team members were assigned.

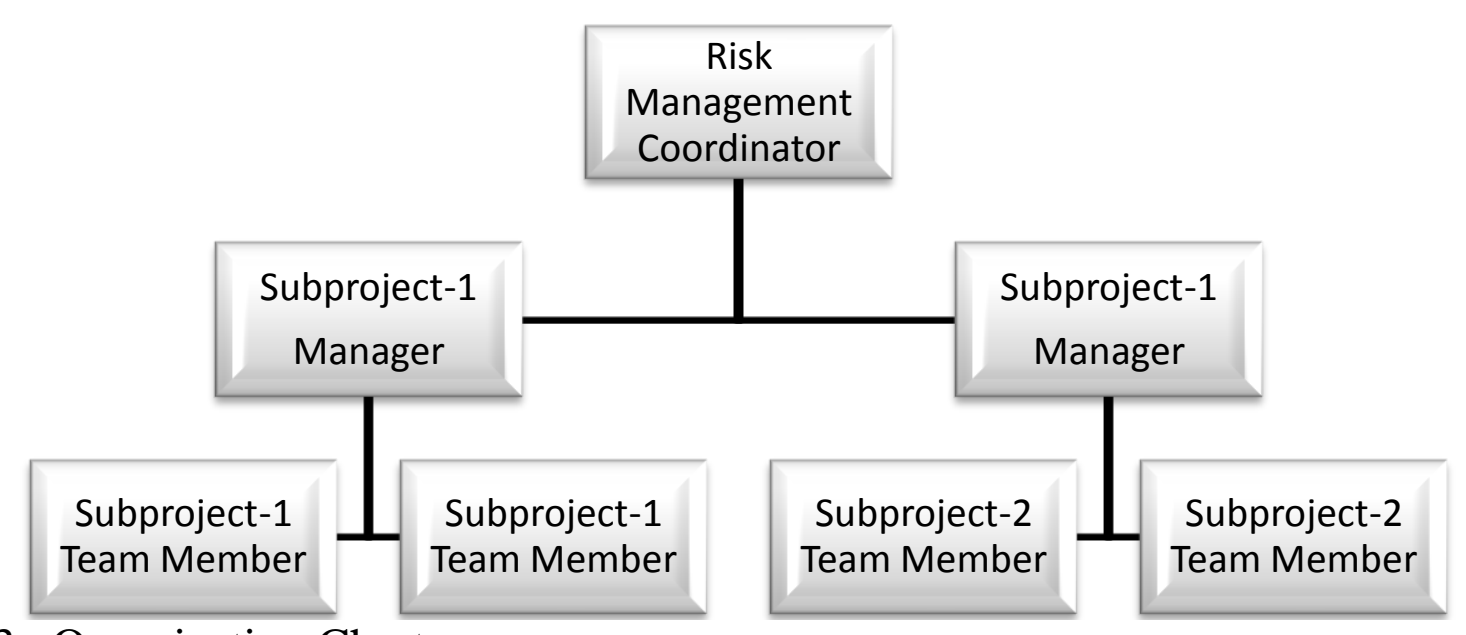

Fig. 3. Organization Chart

\begin{tabular}{|c|l|}
\hline & - Manages RMP \\
RISK & - Updates Risk and Event Template \\
- Informs the Management about the situation of the project's \\
risks \\
MANAGEMENT & - Monitors and assesses corrective actions \\
COORDINATOR & - Distributes risk information among all interested parties \\
& - Prepares requested reports and documents \\
& - Supervises Risk Management Plan execution \\
- Coordinates Risk Identification actions & - Coordinates Qualitative Risk Analysis \\
- Coordinates Quantitative Risk Analysis & - Contributes to risk prioritization \\
& - Coordinates identification of people responsible for risks \\
- Supervises fulfillment of risk response plans once the \\
triggering event is detected
\end{tabular}


Fenollera, M. \& Lorenzo, J.: Risk Management: an Adaptation for a SME

\begin{tabular}{|c|l|}
\hline & - Informs about risk status in all projects \\
\hline SUBPROJECT & $\begin{array}{l}\text { - Contributes to Risk Identification } \\
\text { - Contributes to Qualitative Risk Analysis } \\
\text { MANAGER } \\
\text { - Contributes to Quantitative Risk Analysis } \\
\text { - Contributes to risk prioritization } \\
\text { - Executes risk response planning once the triggering event is } \\
\text { detected } \\
\text { - Informs about the project's risk status }\end{array}$ \\
\hline PROJECT TEAM & $\begin{array}{l}\text { - Directs Risk Identification actions } \\
\text { - Supervises Qualitative Risk Analysis } \\
\text { - Is in charge of Quantitative Risk Analysis } \\
\text { - Contributes to risk prioritization } \\
\text { - Contributes to the identification of people responsible for } \\
\text { risks } \\
\text { - Informs Coordinator about risk management regarding new } \\
\text { detected risks } \\
\text { - Develops mitigation strategies in the project under his } \\
\text { responsibility } \\
\text { - Reviews and advises on changes in detected risks and actions } \\
\text { recommended to mitigate their impact }\end{array}$ \\
\hline
\end{tabular}

Tab. 2. Roles and Responsibilities

- Course of action: Next picture, Figure 4, graphically shows the general course of action and the people responsible.

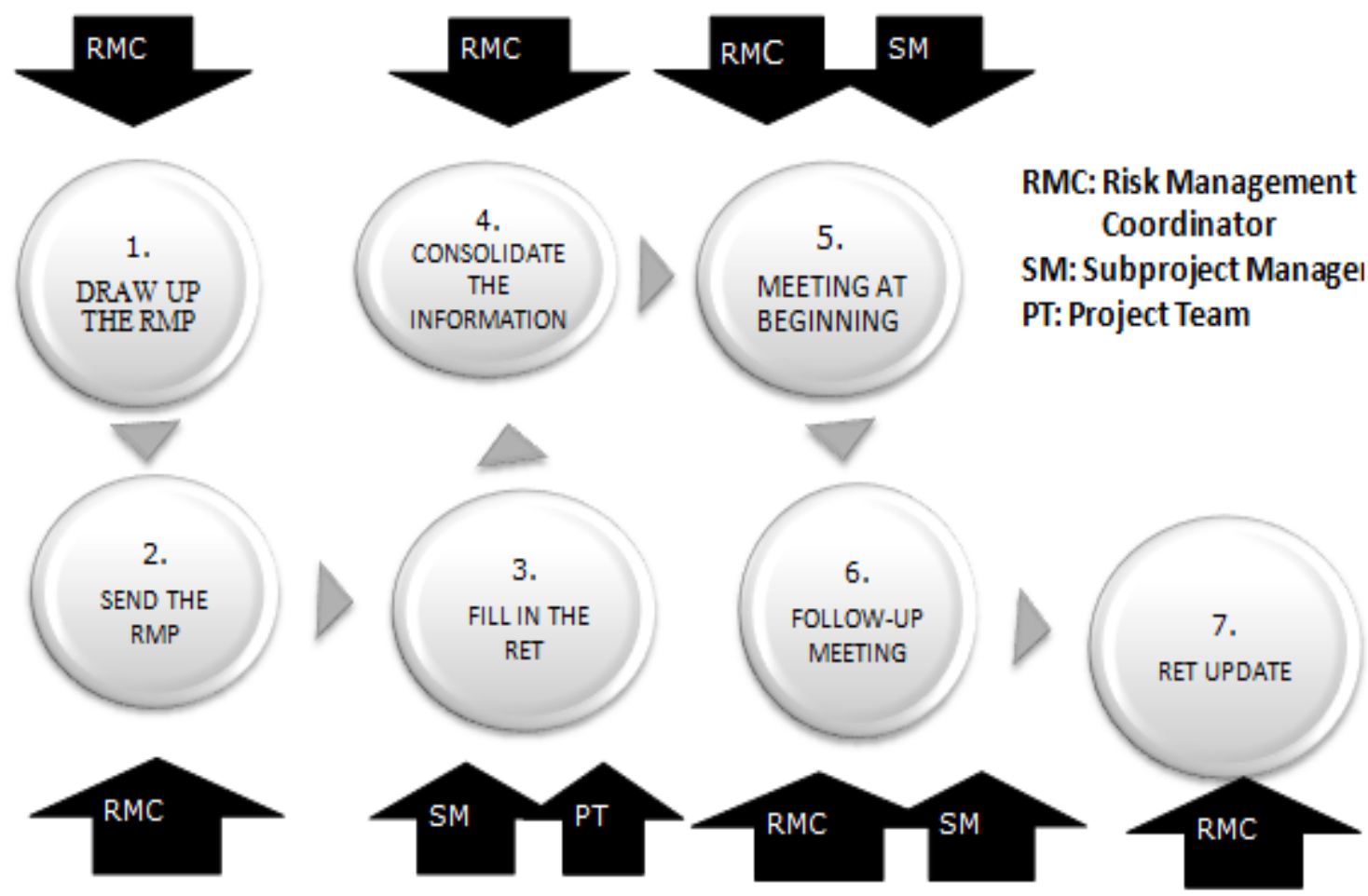

Fig. 4. Course of action 
The course of action was in turn divided into two procedures according to the risk management phase it is in. The first one would be identification, analysis and action plan described in Table 3 (a), and the second one, monitoring and control described in Table 3 (b). Tables 3 show actions and people responsible.

\begin{tabular}{|l|}
\hline \multicolumn{1}{|c|}{ IDENTIFICATION, ANALYSIS AND ACTION PLAN } \\
\hline $\begin{array}{l}\text { 1- The Risk Management Coordinator will send the Risk Management Plan to each } \\
\text { of the Sub-project Managers. }\end{array}$ \\
\hline $\begin{array}{l}\text { 2- The Risk Management Coordinator will request all of Sub-project Manager to } \\
\text { send Risk and Event Template (RET) filled in as regards their project's risks. }\end{array}$ \\
\hline 3- Sub-project Manager will conduct the actions included in actions table. \\
\hline $\begin{array}{l}\text { 4- Once the RET is received, the Risk Management Coordinator will consolidate } \\
\text { the information. }\end{array}$ \\
\hline $\begin{array}{l}\text { 5- A meeting will be held where the Coordinator and people responsible for the } \\
\text { project will establish risk priority, thus elaborating the final RET; also, a } \\
\text { responsible person will be selected for the risks to be monitored, and another for } \\
\text { checking on the evolution of those risks not being monitored for the moment. }\end{array}$ \\
\hline
\end{tabular}

Tab. 3. (a) Identification, analysis and action plan procedure

\begin{tabular}{|c|}
\hline MONITORING AND CONTROL \\
\hline $\begin{array}{l}\text { 1- The Risk Management Coordinator and Sub-project Managers will deal with the } \\
\text { identification, analysis and actions regarding the project's new risks. }\end{array}$ \\
\hline $\begin{array}{l}\text { 2- The Risk Management Coordinator, together with Sub-project Managers, will } \\
\text { review risk-related actions, periodically at each internal monitoring meeting and } \\
\text { specifically, at any stage of project development, when high exposure risks arise. }\end{array}$ \\
\hline $\begin{array}{l}\text { 3- The Risk Management Coordinator will update the RET as a consequence of the } \\
\text { risk progress and it will be presented as an annex of the Internal Monitoring Report } \\
\text { (IMR). }\end{array}$ \\
\hline $\begin{array}{l}\text { 4- Each Sub-project Managers is to watch over the fulfillment of actions } \\
\text { established in the Risk Management Plan. }\end{array}$ \\
\hline
\end{tabular}

Tab. 3. (a) Identification, analysis and action plan procedure

- Controls: those applied to the project have been as follow:

Review of the actions associated to risks made by the Risk Management Coordinator, monthly through the Internal Monitoring Report (IMR) and specifically when high exposure risks arose. 
Fenollera, M. \& Lorenzo, J.: Risk Management: an Adaptation for a SME

- Metrics: metrics are measures including enough information to alert to potential harm and help identify potential and real risks.

Those established for this Project are included in Table 4, where each of them and their names are defined, and products derived from their implementation are indicated, as well as how to estimate and assess them.

\begin{tabular}{|l|l|l|}
\hline NAME OF METRICS & \multicolumn{1}{|c|}{ DESCRIPTION } & FORMULA \\
\hline 1- No. of risks and impact. & $\begin{array}{l}\text { Number of project's risks } \\
\text { by impact 1,2,3,4 }\end{array}$ & No. of risks \\
\hline 2- No. of risks and probability & $\begin{array}{l}\text { Number of project's risks } \\
\text { by probability 1,2,3,4 }\end{array}$ & No. of risks \\
\hline 3- Risk Priority Number (RPN) & RPN assessment & Criteria \\
\hline 4- No. of risks becoming impacts & $\begin{array}{l}\text { Number of project's risks } \\
\text { that became impacts }\end{array}$ & No. of risks \\
\hline
\end{tabular}

Tab. 4. Risk Management Plan Metrics

- Activities: Table 5 shows actions and techniques specific for each of the stages of risk management procedure.

\begin{tabular}{|c|c|c|c|c|c|c|}
\hline$\underset{\mathbb{Z}}{\mathbb{Z}}$ & $\stackrel{8}{2}$ & 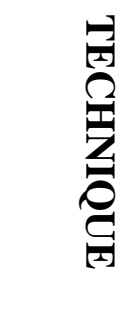 & 党 & 宽 & 可 & 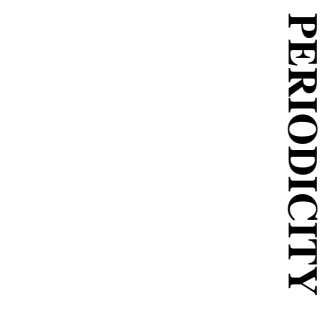 \\
\hline : & 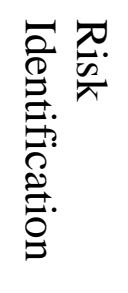 & 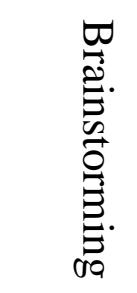 & 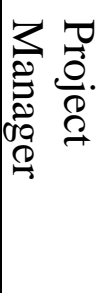 & 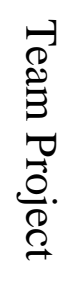 & 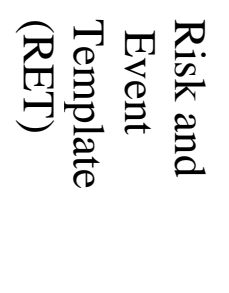 & 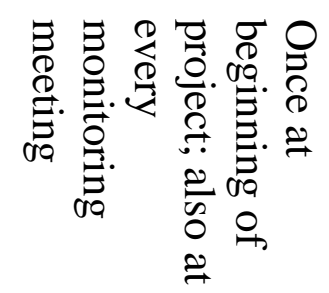 \\
\hline 吾 & 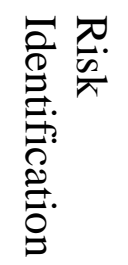 & 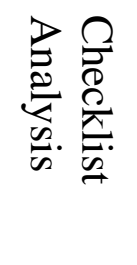 & 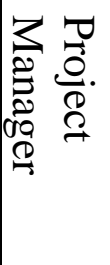 & 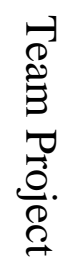 & 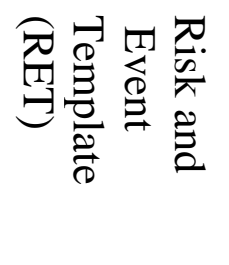 & 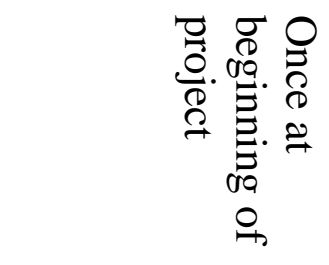 \\
\hline
\end{tabular}




\begin{tabular}{|c|c|c|c|c|c|c|}
\hline 吾 & 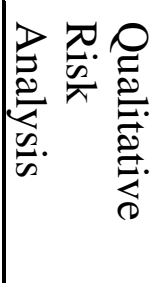 & $\underset{>}{3}$ & 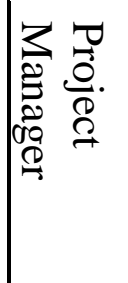 & $\begin{array}{l}\overrightarrow{0} \\
\stackrel{0}{3} \\
0 \\
0 \\
0.0 \\
\stackrel{0}{0}\end{array}$ & 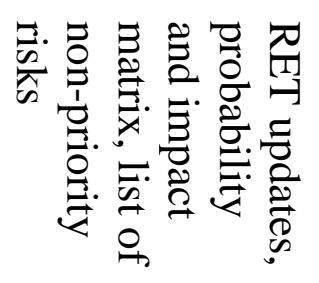 & 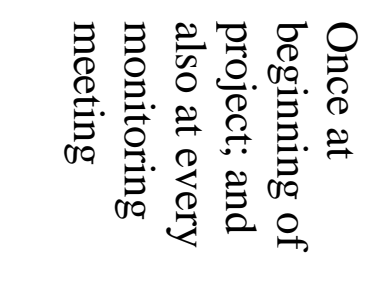 \\
\hline 矛 & 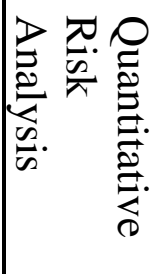 & $\underset{3}{3}$ & 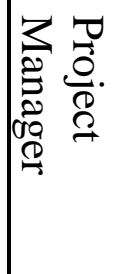 & 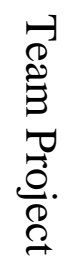 & 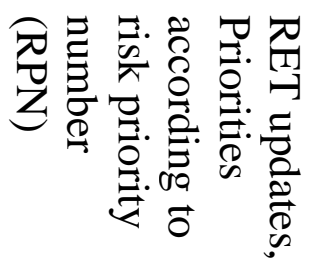 & 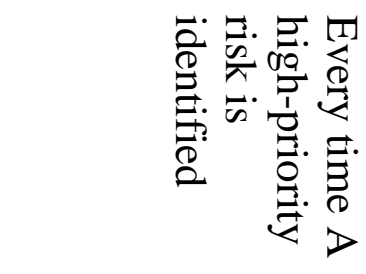 \\
\hline 党 & 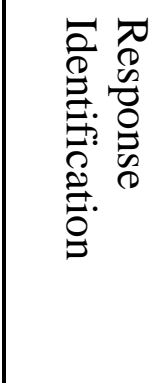 & 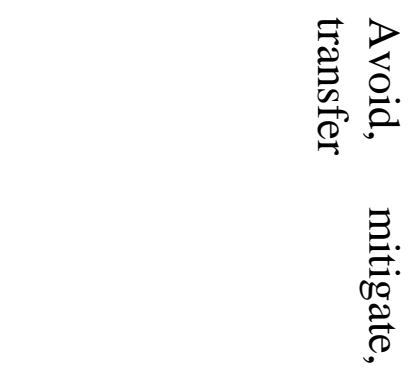 & 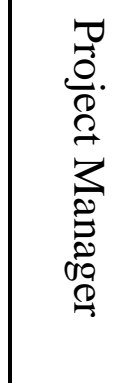 & 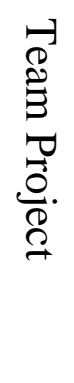 & 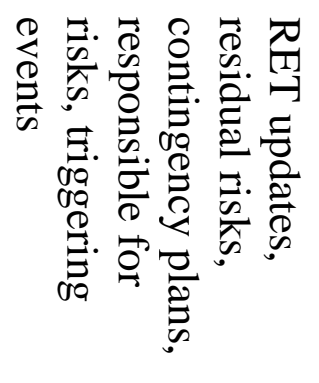 & 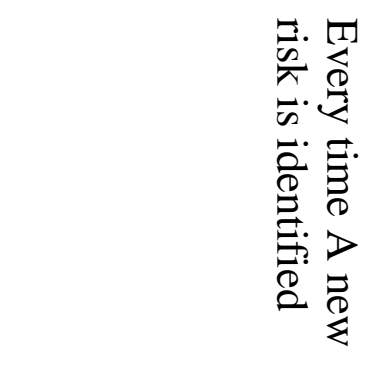 \\
\hline 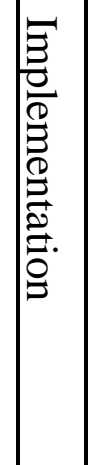 & 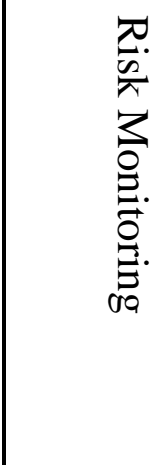 & 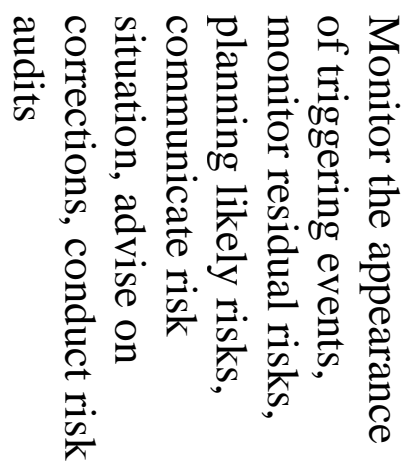 & 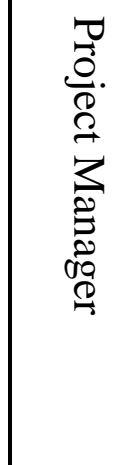 & 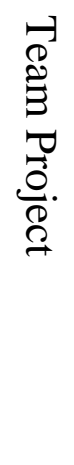 & 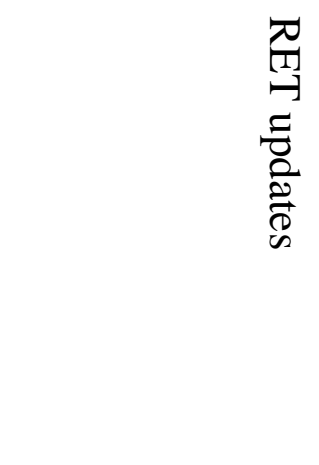 & 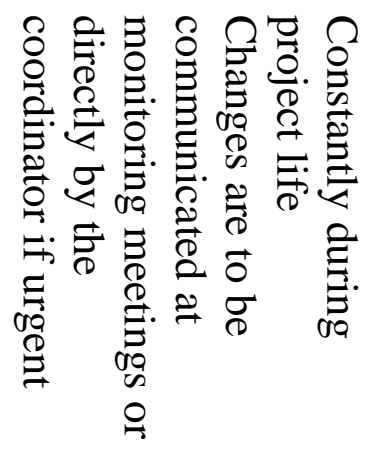 \\
\hline
\end{tabular}

Tab. 5. Risk Management Planning and Implementation Process Activities

As it can be seen, a series of actions were defined in two process groups: planning and implementation, indicating for each of them which techniques were used, who the responsible is, who takes part in that activity, which deliverable is obtained and how often each activity is conducted.

- Records of risks and events: all the information regarding Project risks was recorded in Risk and Event Template.

\section{STEP 2: RISK IDENTIFICATION}

Initially, as the SME used to do before using this methodology, a previous analysis was conducted in order to broadly identify the risks likely to be associated to the Project: what it is made for, what is sought at a technical level, when it is going to be done, with which resources, how much is going to be spent and how it is going to be conducted, and no specific methodology was followed.

Then, as it had been planned in risk management, the techniques proposed by the researchers used to identify risks were brainstorming and checklist analysis. 
As an example, without going into any further details, Figure 5 shows the main categorized risks identified in this Project and in most projects, as listed in specialized bibliography (Lessard and Lessard, 2007; Aloini and collaborators, 2007; among others).

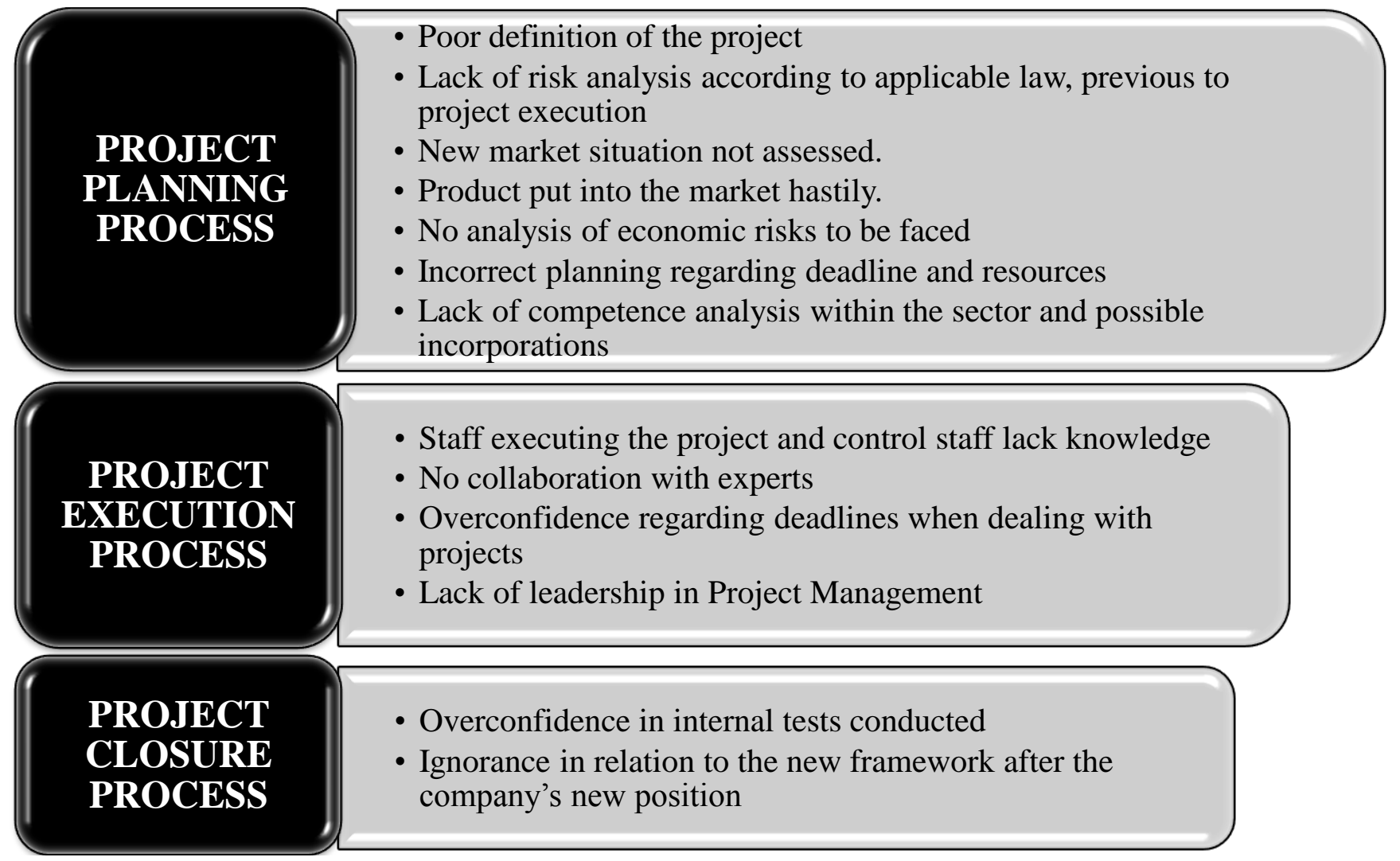

Fig. 5. Identification of Categorized Risks

Risks have been classified according to the process group in which they were identified: project planning, implementation and closure processes in this case. STEPS 3, 4, 5 \& 6: RISK ANALYSIS, ASSESSMENT, HANDLING, MONITORING AND CONTROL

In order to make up for the lack of training of the SME project teams, a simple tool was sought, easy to implement, with clarity as regards information, that is to say, with indicators that could be easily obtained and analyzed, with draft formats that would contribute to the project documents and their future use in other projects.

The Failure Mode \& Effect Analysis (FMEA) was the risk management key tool, since the company was familiar with it but used it with a different purpose. The intention was to have a practical document containing the maximum information in the minimum space.

The FMEA applied to Risk Management includes, on the one hand, a list of risks, prioritized after its assessment based on impact and probability of occurrence ratings, whose product will provide the Risk Priority Number (RPN) and, on the other hand, the strategy to be followed to keep or reduce the number.

Next authors present: risk levels (Table 5), action strategy and criteria depending on the RPN used (Table 6), and probability and impact matrix (Figure 6). 


\begin{tabular}{|l|c|l|l|}
\hline \multicolumn{4}{|c|}{ RISK LEVEL } \\
\hline \multicolumn{1}{|c|}{ IMPACT } & 1 & Unlikely & 1 \\
\hline Low Or Minor & 2 & Very Unlikely & 2 \\
\hline Significant & 3 & Likely & 3 \\
\hline High & 4 & Very Likely & 4 \\
\hline Catastrophic
\end{tabular}

Tab. 5. Risk Levels

\begin{tabular}{|l|l|l|}
\hline \multicolumn{1}{|c|}{ ACTION PLAN } & \multicolumn{2}{c|}{ CRITERIA: RPN } \\
\hline Do not act if rating does not change & Acceptable risk & $1-2,5$ \\
\hline Appearance control: define alerts & Weak risk & $2,5-5$ \\
\hline Reduce & Strong risk & $5-8$ \\
\hline Eliminate & Unacceptable risk & $8-10$ \\
\hline
\end{tabular}

Tab. 6. action strategy and criteria depending on the RPN used

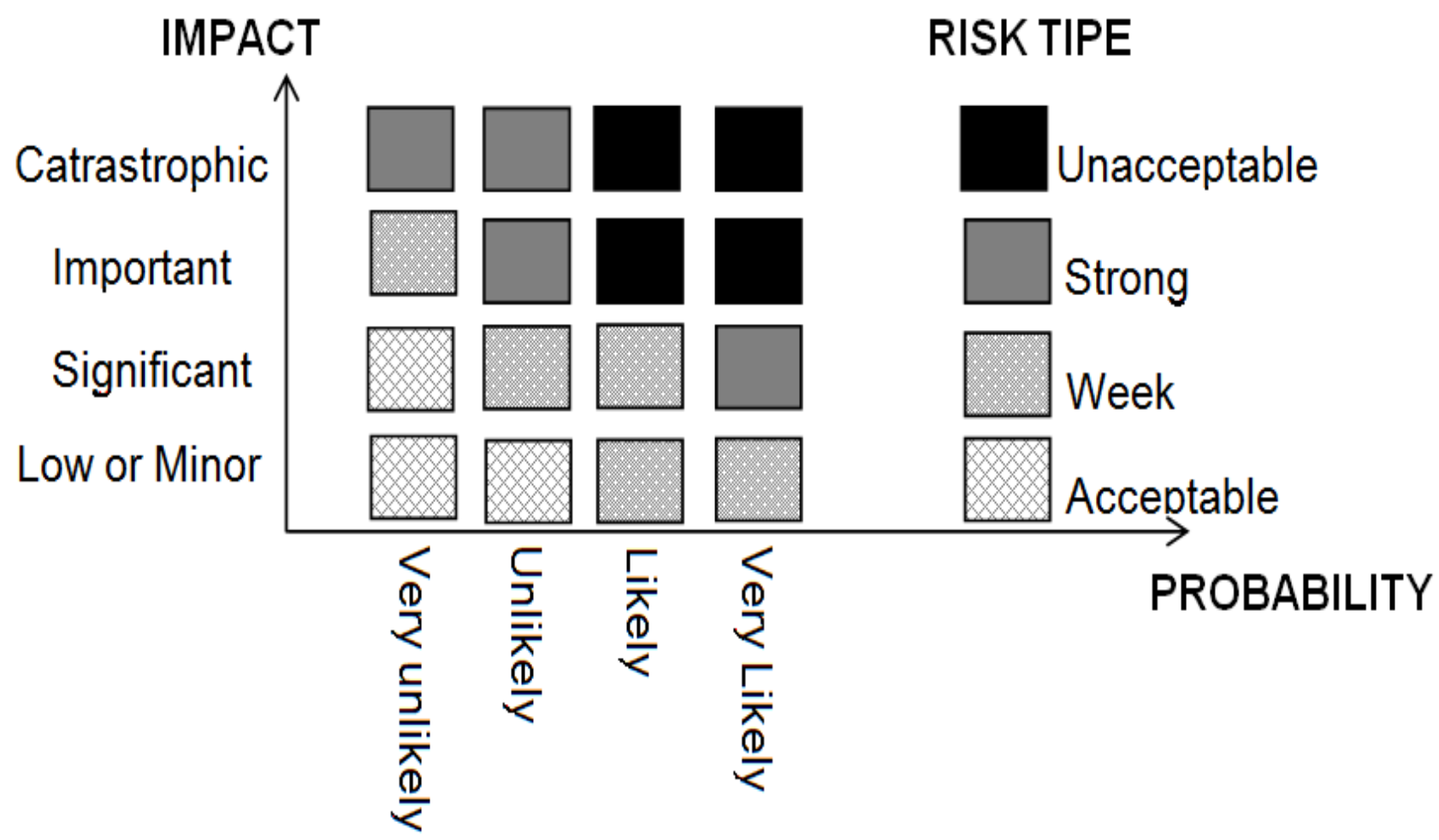

Fig. 6. Identification of categorized risks

Risk assessment has been carried out on the basis of its impact on costs, deadlines and scope, as well as level of possibility of occurrence.

Initially when the project began, a significant part of its risks was identified, analyzed, assessed and recorded in the Risk and Event Template. When we mentioned periodical review in figure 1, in which Risk Management Plan steps were indicated, we meant that the list of risks was always open and throughout the Project periodical reviews of the status of risks already identified were undertaken, adding new risks when considered appropriate. This is what risk monitoring and control is about.

Figures 7 show the FMEA of categorized risks illustrated in figure 5. In Figure 7 (a), risks evaluation was made depending on its impact in the costs, the period and 
Fenollera, M. \& Lorenzo, J.: Risk Management: an Adaptation for a SME

the scope, as well as the occurrence probability level. In Figure 7 (b), actions to be adopted, responsible people and periods are shown on the right side.

\begin{tabular}{|c|c|c|c|c|c|c|c|c|}
\hline \multicolumn{9}{|c|}{ PROJECT RISK ANALYSIS } \\
\hline \multicolumn{2}{|c|}{$\begin{array}{l}\text { PROJECT CODE: HJ0319810 } \\
\text { PROJECT DESCRIPTION: } \\
\text { Fender Davits }\end{array}$} & \multicolumn{5}{|c|}{$\begin{array}{l}\text { PROJECT MANAGER: Borja } \\
\text { González } \\
\text { DATE: } 10 / 17 / 2009\end{array}$} & \multicolumn{2}{|c|}{$\begin{array}{l}\text { REVISION } \\
\quad N^{0}: 8 / 1\end{array}$} \\
\hline \multicolumn{9}{|c|}{ RISK IDENTIFICATION AND PRIORITIZATION } \\
\hline \multirow{2}{*}{$\begin{array}{l}\text { PROJECT } \\
\text { STAGE }\end{array}$} & \multirow{2}{*}{\multicolumn{2}{|c|}{ ASSOCIATED RISKS }} & \multicolumn{3}{|c|}{ IMPACT } & \multirow{2}{*}{\multicolumn{2}{|c|}{$\begin{array}{l}\text { PROBABIL } \\
\text { ITY }\end{array}$}} & \multirow[b]{2}{*}{ RPN } \\
\hline & & & $\mathrm{COS}$ & PERI & $\mathrm{SCOF}$ & & & \\
\hline Planning & 1- Management $n$ & implied & 3 & 4 & 3 & & 4 & 5,7 \\
\hline \multirow{5}{*}{ Planning } & \multicolumn{2}{|c|}{ 2- Poor objective definition } & 3 & 4 & 4 & & 3 & 5,7 \\
\hline & \multicolumn{2}{|c|}{ 3- No resource planning } & 3 & 4 & 2 & & 3 & 2,9 \\
\hline & \multicolumn{2}{|c|}{$\begin{array}{l}\text { 4- Staff designated for the project is } \\
\text { Not trained regarding the } \\
\text { Management } \\
\text { system to be implemented }\end{array}$} & 2 & 4 & 4 & & 4 & 5 \\
\hline & \multicolumn{2}{|c|}{ 5- Project Manager lacks leadership } & 2 & 4 & 4 & & 4 & 5 \\
\hline & \multicolumn{2}{|c|}{$\begin{array}{l}\text { 6- Company staff is not informed } \\
\text { about } \\
\text { new system implications }\end{array}$} & 2 & 3 & 4 & & 4 & 3,8 \\
\hline \multirow{4}{*}{ Execution } & \multicolumn{2}{|c|}{$\begin{array}{l}\text { 7- Auditor is not aware of the } \\
\text { company's processes }\end{array}$} & 1 & 3 & 3 & & 2 & 0,7 \\
\hline & \multicolumn{2}{|c|}{$\begin{array}{l}\text { 8- Management does not control } \\
\text { Project progress }\end{array}$} & 3 & 4 & 3 & & 4 & 5,7 \\
\hline & \multicolumn{2}{|c|}{ 9- Unrealistic deadlines and budgets } & 3 & 3 & 1 & & 4 & 1,4 \\
\hline & \multicolumn{2}{|c|}{$\begin{array}{l}\text { 10- Project Manager lacks } \\
\text { implication }\end{array}$} & 2 & 4 & 2 & & 3 & 1,8 \\
\hline Closure & \multicolumn{2}{|c|}{$\begin{array}{l}\text { 11- System maintenance not } \\
\text { planned }\end{array}$} & 4 & 2 & 3 & & 4 & 3,8 \\
\hline
\end{tabular}

Fig. 7. (a). Failure Mode \& Effect Analysis (FMEA): Risk evaluation and prioritization. Source: Marcelino-Sádaba, Amaya-Ezcurdia (Dyna 2010) 


\begin{tabular}{|c|c|c|c|c|c|c|c|}
\hline \multicolumn{8}{|c|}{ PROJECT RISK ANALYSIS } \\
\hline \multicolumn{2}{|c|}{$\begin{array}{l}\text { PROJECT CODE: HJ0319810 } \\
\text { PROJECT DESCRIPTION: Fender Davits }\end{array}$} & \multicolumn{4}{|c|}{$\begin{array}{c}\text { PROJECT MANAGER: Borja González } \\
\text { DATE: 10/17/2009 }\end{array}$} & \multicolumn{2}{|c|}{ REVISION No: 8/1 } \\
\hline \multicolumn{8}{|c|}{ RISK HANDLING } \\
\hline \multirow{2}{*}{ ACTION } & \multirow{2}{*}{$\begin{array}{c}\text { PEOPLE } \\
\text { RESPONSIBLE }\end{array}$} & \multirow{2}{*}{ PERIOD } & \multicolumn{3}{|c|}{ IMPACT } & \multirow{2}{*}{ PROB. } & \multirow{2}{*}{ RPN } \\
\hline & & & $\operatorname{cosT}$ & PERIOD & SCOPE & & \\
\hline $\begin{array}{l}\text { 1- Management } \\
\text { assumes leadership }\end{array}$ & Management & Project's length & 2 & 2 & 2 & 2 & 0,6 \\
\hline $\begin{array}{l}\text { 2- Clearly define } \\
\text { measurable objectives }\end{array}$ & $\begin{array}{l}\text { Management/ } \\
\text { Quality Manager }\end{array}$ & 1 week & 2 & 2 & 2 & 2 & 0,6 \\
\hline $\begin{array}{l}\text { 3-Deadline fulfillment } \\
\text { is tracked }\end{array}$ & Management & Project's length & 2 & 3 & 2 & 2 & 0,9 \\
\hline $\begin{array}{l}\text { 4- General and specific } \\
\text { training program }\end{array}$ & HR Responsible & 1 week & 2 & 3 & 3 & 2 & 1,4 \\
\hline $\begin{array}{c}\text { 5- Management } \\
\text { assumes leadership }\end{array}$ & Management & Project's length & 2 & 2 & 3 & 2 & 0,9 \\
\hline 6- Informal lecture & $\begin{array}{l}\text { Management/ } \\
\text { Quality Manager }\end{array}$ & 1 week & 2 & 2 & 2 & 3 & 0,9 \\
\hline \multicolumn{8}{|l|}{$7-$} \\
\hline $\begin{array}{l}\text { 8- Management } \\
\text { assumes leadership }\end{array}$ & Management & Project's length & 3 & 3 & 3 & 2 & 2,1 \\
\hline \multicolumn{8}{|l|}{ 9- } \\
\hline \multicolumn{8}{|l|}{$10-$} \\
\hline $\begin{array}{l}\text { 11-System maintenance } \\
\text { plan is conducted }\end{array}$ & Quality Manager & 1 month & 2 & 2 & 2 & 1 & 0,6 \\
\hline
\end{tabular}

Fig. 7. (b). Failure Mode \& Effect Analysis (FMEA): Risk handling. Source: Marcelino-Sádaba, Amaya-Ezcurdia (Dyna 2010)

After this description (a bit theoretical), below we are listing some of the most significant activities in the success of this project carried out by its "skateholders", derived from the risk analysis:

- The customer determined the SME culture and its existing systems: he was at the SME personally from the order's acceptance, with his Project team made up of five people, one of them the external auditor who was the risk management coordinator, to know in person what kind of company he was dealing with and which its strengths and weaknesses were.

- The customer compiled processes, procedures and factual information: the SME was requested a lot of information about suppliers, their certifications; the customer personally visited them and even visited the Technology Centre Aimen; there they saw the tests and controls undertaken to obtain certificates, and visited 
the technical office, validating the whole design, approving calculations, and working closely with the researchers.

- Business necessities, suppositions and restrictions were documented. All kinds of reports were requested: about suppliers, materials, procedures, finishes ...

- A long period of time (4 months) was devoted to define and to establish management plans related to planning, creating the wording of the project's scope.

- Charts corresponding to the customer's project and the SME were created; this was something that the company did not used to do, defining the roles and responsibilities of each team member, contributing to conflict avoidance.

- Great importance was given to determine quality standards, processes and metrics requiring them even from our suppliers. They implemented approved changes, defect repair and preventive and corrective actions.

- Weekly follow-up meetings through videoconferences took place. All the customer's team members attended the meeting to deal with the launching of the Project for one week.

- The documents delivered were thoroughly controlled and registered. 157 documents were created with different updating intervals which extended from 04/28/09 to 04/19/10. Most of the documents were proposed by the customer, who gave their templates to the SME.

- Cost control took place throughout the project's life cycle, analyzing any difference or extra cost through its corresponding report justification and the actions to be taken to minimize such differences.

- The customer exerted a lot of pressure, together with the SME, on the hydraulic equipment supplier (Neuwalme) aimed at taking corrective actions due to the delay in the delivery of the equipment. They contacted the supplier directly to back the SME and exert more pressure, and so the delay was reduced to 2 weeks.

Most of these actions were imposed by the customer, who encouraged and guided the SME through the right risk management. Researchers, very familiar with SME and its characteristics, were used as a bridge to facilitate a suitable implementation of these impositions. Despite the SME being initially shocked at this working procedure and somehow reluctant to the tight customer control, soon realised the advantages of this new working procedure and collaborated in their implementation.

\section{Results}

With the design of the Risk Management Plan described, the following activities have been targeted: risk management planning; the identification, qualitative analysis, and quantitative analysis of risks; planning of response of risk; and supervision and control of the answers of risk. A simple and smooth risk management has been implemented, obtaining diverse templates and deliverables applicable in the future. This has led to avoid and minimize those events with negative impacts on the project's results and to take advantage of the positive ones.

The results obtained based in the project's previous considerations are shown in Table below: 


\begin{tabular}{|l|c|c|}
\cline { 2 - 3 } \multicolumn{1}{c|}{} & THEORETICAL & REAL \\
\hline Deadline: & 30-day average delay & $\begin{array}{c}\text { Within the stipulated period; } \\
\text { no delays }\end{array}$ \\
\hline Price: & $\begin{array}{c}1.300 .000 € \\
(22 \% \text { of turnover) }\end{array}$ & $\begin{array}{c}1.300 .000 € \\
(22 \% \text { of turnover })\end{array}$ \\
\hline Cost: & $\begin{array}{c}920,000 € \\
(800.000 €+15 \%)\end{array}$ & $\begin{array}{c}864,000 € \\
(800.000 €+8 \%)\end{array}$ \\
\hline Benefit: & $\begin{array}{c}29 \% \text { benefit } \\
\text { (cost of } 920,000 €)\end{array}$ & $\begin{array}{c}33,54 \% \text { benefit } \\
(\text { cost of } 864,000 €)\end{array}$ \\
\hline Cost increase: & $15 \%$ increase from budget & $8 \%$ increase from budget \\
\hline $\begin{array}{l}\text { Customer } \\
\text { satisfaction: }\end{array}$ & $\begin{array}{c}\text { Survey average rating of } 2 \\
\text { (scale } 2-5)\end{array}$ & $\begin{array}{c}\text { Survey average rating of } 4 \\
\text { (scale 2- 5) }\end{array}$ \\
\hline Product quality: & medium & high \\
\hline
\end{tabular}

Tab. 7. Results

As it can be verified in Table 7, the order's delivery objective, fulfilling all its specifications, has been extensively carried out, both in delivery date and in costs reduction, quality, higher benefit and customer satisfaction.

The methodology created in this document provides the framework for the SME to accomplish their project risk tasks in an organized and well defined process. This methodology also provides many of the tools and techniques needed to manage successful projects.

\section{Conclusion}

The main consequences of this PMI implementation were:

- It was the milestone in this project's success for a SME motivated to be consolidated in a competitive sector and to enter a new market; and has set a turning point in its working method.

- One of the negative risks associated to a new methodology implementation is to go back to previous practice and bad habits and this can become evident if the advantage of using the new methodology is not clearly appreciated within the organization or there is a lack of motivation among the staff. In the case study, although starting from a new situation, this negative risk is not such, since in view of the results obtained the staff is highly motivated to continue with the "best practices" included in PMBok (2008).

- The principal positive implication is that, with the mentioned motivation, the SME was receptive, in a near future, to reaffirm the concepts implemented in this pilot experience, and to be able to continue implanting the Process Groups of the PMI methodology in other projects, not only in the Risk Management Area but integrating the rest of the knowledge Areas. 


\section{Acknowledgements}

The authors would like to thank all people who contributed, both direct and indirect, to this study: the customer who has been the spark which ignites all this process; the researchers from Engineering Projects Area at University of Vigo, who work full-time; and we are also very grateful for the cooperation and interest of Industrias Ferri, S.A. It would not have been possible without their help.

\section{References}

Aloini D.; Dulmin, R. \& Mininno, V. (2007). Risk management in ERPO project introduction: Review of the literature. Information \& Management. Vol. 44, No. 6, September 2007, pp. 547-567, ISSN 0378-7206

Blanc-Alquiler, A.M. \& Lagasse-Tignol, M.H. (2006). Risk management in smalland medium-sized enterprises, Production Planning \& Control, Vol. 17, No. 3, April 2007, pp. 273-282, ISSN 0953-7287

Bovee, R. \& Ruwaard, M. (2004). Operations Management, a new process, Second edition, Mansystems, ISBN 90-440-0201-5, Nederland

Delisle, S. \& J. St-Pierre (2003). SME Projects: A Software for the Identification, Assessment and Management of Risksll, 48th World Conference of the International Council for Small Business (ICSB- 2003), Belfast, June 2003, CD-ROM proceedings

Lessard, C. \& Lessard, J. (2007). Project Management for Engineering Design, Synthesis Lectures on Engineering, Vol. 2, No. 1, pp. 1-110, ISSN: 1939-5221

Marcelino-Sádaba, S. \& Perez-Ezcurdia A. (2010). Gestión del riesgo en proyectos abordados por pymes, DYNA. Vol. 85, No.6, Sept 2010,pp.504-512, ISSN 0012-7361

Nagyova, A. \& Pacaiova, H. (2009). How to Build Manual for Key Performance Indicators - KPI. In: DAAAM International Scientific Book 2009, B. Katalinic (Ed.), pp. (135-142), DAAAM International, ISBN 978-3-901509-69-8, Vienna, Austria

Project Management Institute (2008). A Guide to the Project Management Body of Knowledge (PMBOK® Guide) - Fourth Edition, Project Management Institute, ISBN 978-1-933890-51-7, USA

Project Management Institute (2009). Practice Standar for Project Risk Management, Project Management Institute, ISBN 978-1-933890-38-8,

Rosu, S.M.; Dragoi,G.; Guran M. \& Dragomirescu, C. (2010). The SMEs Knowledge Management: Professional Risk Assessment Using a KBS. In: DAAAM International Scientific Book 2010, B. Katalinic (Ed.), pp. 709-724, DAAAM International, ISBN 978-3-901509-74-2, Vienna, Austria

Rowe, S.F. (2007). Project management for small projects, Management Concepts, ISBN: 156726185X, Vienna, USA.

Taylor, S.; Lloyd, V. \& Rudd, C. (2007). ITIL ${ }^{\circledR}$ Service Design. 3th Version, The Stationery Office Books, ISBN 978-0-11-331047-0, United Kingdom.

Turner. J.R.; Ledwith, A. \& Kelly, J. (2009). "Project management in small to medium-sized enterprises: A comparison between firms by size and industry", International Journal of Managing Projects in Business, Vol. 2, No. 2, pp.282 - 296, ISSN 1753-8378 